\title{
Association between Duration Working with Lung Disruption Condition using Pulmonary Vital Capacity (PVC) test on Lathe Worker at Yogyakarta, Indonesia
}

\author{
Abdul Rohim Tualeka ${ }^{1}$, Hu jatul Kalamillah ${ }^{1}$, Wulan Meidikayanti ${ }^{2}$ \\ ${ }^{1}$ Department of Occupational Health and Safety, Faculty of Plic Health, Airlangga University, Indonesia, \\ ${ }^{2}$ Faculty of Public Health, Airlangga University, Indonesia
}

\begin{abstract}
Background: For the past decade, pulmonary fibrosis occurred due to excessive connective tissue in the lung caused by inflammation. Inhaled aluminum constantly has been thought as a key factor for pulmonary fibrosis for workers. Within the next few years, aluminum ash would become toxic inside the body and cause a hardening or fibrosis of the lungs. The present paper aims to analyze association between duration working with lung disruption condition on lathe workers in $\mathrm{Z}$ industry, Yogyakarta.
\end{abstract}

Method: The research used a cross-sectional design. The sample was 16 lathe workers at $\mathrm{Z}$ Industry, Yogyakarta. Independent variable were age, period employment, and duration of work. The dependent variable was lung disruption. Measurement of lung disruption used pulmonary vital capacity test. Data analysis was using chi-square test and Risk Prevalence (PR).

Result : Age and the period of employment had a quite weak association with lung disruption $(p=0,158 ; 0,279)$. While the duration of work has a strong association with lung disruption $(p=0,729)$.

Conclusion: Duration of work has a strong association with lung disruption. This is caused by a worker which inhaled aluminum dust continuously, aluminum dust would be accumulated, becomes toxic and caused parenchyma tissues damaged in the lung.

Keywords: duration working, lung discruption, PVC, lathe worker

\section{Introduction}

Dust, steam, gases that surrounding the workers in the work environment would disrupt productivity and health of the workers. It can also lead to a reduction of comfort, eyesight, the impaired respiratory function of pulmonary disorders. The size, shape, concentration, solvency, chemical

\section{Corresponding author}

\section{Abdul Rohim Tualeka}

Occupational Health and Safety Department, School of Public Health, Airlangga University Kampus C, Jalan Mulyorejo, Surabaya, 60115, Indonesia, Tel: +62 31 5920948, Fax: +62 315924618 , E-mail: inzut.tualeka@gmail.com properties and long exposure to dust is the cause of the onset of the disorder pulmonary function ${ }^{1}$.

Factors which influence substance toxicity are characteristics exposure in the form of an exposure dose and exposure duration. Working environment also has an impact on toxicity chemical substance such as temperature and humidity. A related hypothesis maintains that individual susceptibility such as age, gender, weight, nutritional status, a history of the disease also has relation with chemical toxicity in the body.

CV Z Yogyakarta is one of the companies in the field aluminum metal industry which produces household appliances made from aluminum. One of the processes that are has a risk for inhaling aluminum dust is lathing process. Previous study stated that $66.6 \%$ lathe workers have decline pulmonary vital capacity. Meanwhile, $40 \%$ 
oflathe workers have a misbehaving lungs disturbance in the form of restrictive disorders ${ }^{2}$.

The purpose of this research is to analyze association between duration working, age, and period employment with lung disruption condition at lathe workers in Z Industry, Yogyakarta

\section{Material and Method}

This research was using a cross-sectional design. The research population was the workers on lathe section at $\mathrm{Z}$ Industry. The research sample was 16 lathe workers in $\mathrm{X}$ industry at Yogyakarta. Independent variables were sex, employment period, and working duration. The dependent variable was lung disruption. Dust total concentration is carried out by the gravimetric method with has dust EPAM is done on the second point lathe location ${ }^{3}$. Measurement of pulmonary vital capacity (FVC) measured with a spirometer. Analysis of test data using chisquare test and Risk Prevalence (PR) to know its association between variables.

\section{Result}

Age, Employment Period and Duration of Work

Table 1. Distribution of age on Lathe section Worker at Z Industry on October 2017

\begin{tabular}{|l|l|l|}
\hline Variable & Frequency & Percentage (\%) \\
\hline Age & & \\
\hline $26-45$ years & 8 & 50 \\
\hline$>45$ years & 8 & 50 \\
\hline Employment Period & & \\
\hline $5-10$ years & 4 & 25 \\
\hline$>10$ years & 12 & 75 \\
\hline Duration of Work & & \\
\hline$\leq 8$ hours/day & 16 & 100 \\
\hline$>8$ hours/day & 0 & 0 \\
\hline
\end{tabular}

Table 1 showed lathe worker with age range 26-45 has same percentage of workers whose has aged more than 45 years. The youngest age of lathe workers is 32 years old, while the oldest age is 53 years. $25 \%$ of lathe workers have employment period on 5-10 years. While working period over 10 years occurs with 12 people or $75 \%$ of the total lathe workers. The working time is less than 5 years is not written on the chart. This is because there are no a lathe part workers working less than 5 years. The working period at the shortest part of the lathe worker is 7 years old and the longest working period i.e. 30 years. All of lathe worker have duration work less than to 8 hours/ day.

Total Dust Level at Two Location on Lathe Workplace

Tabel 2. Distribution of Total Dust Levels on the Lathe Workplace in November 2017

\begin{tabular}{|l|l|}
\hline Measurement Spot & Total Dust levels $\left(\mathbf{m g} / \mathbf{m}^{\mathbf{3}}\right)$ \\
\hline East & 0.459 \\
\hline West & 0.652 \\
\hline
\end{tabular}

Based on the results on table 2, measurement of total dust levels on the two lathe section on $\mathrm{Z}$ Industry still under threshold limit value (TLV) set by Permenakertrans RI numbers Per 13/ Download/X/2011 i.e. $10\left(\mathrm{mg} / \mathrm{m}^{3}\right)^{4}$.

\section{Lung Disruption}

The condition of lung disruption at lathe worker's differentiated into normal and abnormal based by the pulmonary vital capacity test. Distribution of lung disruption on lathe worker can be seen in the table below.

Tabel 3. Distribution of Lung Disruption on Lathe Worker at Z Industry October 2017

\begin{tabular}{|l|c|c|}
\hline Lung Disruption & Frequency & $\begin{array}{c}\text { Percentage } \\
\mathbf{( \% )}\end{array}$ \\
\hline Normal & 13 & 81 \\
\hline Abnormal & 3 & 19 \\
\hline Total & 16 & 100 \\
\hline
\end{tabular}

Based on the table above can be known by as much as 13 workers in the lathe section at $X$ or $81 \%$ of workers had normal pulmonary vital capacity, while 3 person workers or $19 \%$ experienced disruption lung. The restriction is usual form which occurred from pulmonary impairment. Workers who experience mild restriction 
has $65 \% \mathrm{FVC}$ for lowest and highest FVC is $73 \%$.

Association between Age, Employment Period and Duration of Work with Lung Disruption

Tabel 4. Association cross tabulation between Age with Lung Disruption Condition On Lathe Worker at Z Industry, Yogyakarta

\begin{tabular}{|c|c|c|c|c|c|c|c|c|}
\hline \multirow{3}{*}{ Variable } & \multicolumn{4}{|c|}{ Lung Disruption } & \multicolumn{2}{|c|}{ Percentage } & \multirow{3}{*}{$\begin{array}{l}\text { Coef ficient } \\
\text { Contingency }\end{array}$} & \multirow{3}{*}{ Risk Prevalence } \\
\hline & \multicolumn{2}{|c|}{ Normal } & \multicolumn{2}{|c|}{ Abnormal } & \multirow{2}{*}{$\mathbf{N}$} & \multirow{2}{*}{$\%$} & & \\
\hline & $\mathbf{N}$ & $\%$ & $\mathbf{N}$ & $\%$ & & & & \\
\hline \multicolumn{9}{|l|}{ Age } \\
\hline $26-45$ years & 7 & 87,5 & 1 & 12,5 & 8 & 100 & \multirow{2}{*}{0,158} & \multirow{2}{*}{ - } \\
\hline$>45$ years & 6 & 75 & 2 & 25 & 8 & 100 & & \\
\hline $5-10$ year & 4 & 100 & 0 & 0 & 4 & 100 & \multirow{2}{*}{0,267} & \multirow{2}{*}{ - } \\
\hline$>10$ year & 9 & 75 & 3 & 25 & 12 & 100 & & \\
\hline \multicolumn{9}{|c|}{ Duration of Work } \\
\hline$\leq 8$ hours/day & 8 & 100,0 & 0 & 0,0 & 8 & 100,0 & \multirow{2}{*}{0.729} & \multirow{2}{*}{1.6} \\
\hline$>8$ hours/day & 5 & 62,0 & 3 & 37,5 & 6 & 100,0 & & \\
\hline
\end{tabular}

Based on table 4 worker who suffered a pulmonary function disruption as much as 1 person or of $12.5 \%$ of all workers aged $26-$ 45 years. While 2 people or $25 \%$ of all workers aged more than 45 years experiencing disorders pulmonary function. Contingency coefficient based on the results obtained low association $(\mathrm{p}=0,158)$ between lung disruption and age lathe worker at $\mathrm{Z}$ Industry.

No worker who has 5-10 year working period has a misbehaving lung. As many as 10 people or $25 \%$ of workers who worked over 10 years suffering from pulmonary disruption. Based on the results of the contingency coefficient is 0.267 . This means there is weak relationships between employment period with lung disruption condition on lathe workers in Industri X.

Based on cross tabulations between lung disruption conditions and duration working mentioned that there is a very strong relationship with coefficient contingency 0.729 while prevalence risk 1.6. This causes that someone who has a working duration more than 8 hours/day has risk 1.6 times will have abnormal lung condition than someone.

\section{Discussion}

Age

The age of workers based on the results of the questionnaire showed that workers in the lathe parts X Industry consist only of the age of 2645 years and more than 45 year. No lathe worker aged 17 25 years. This is because all the workers began work at $Z$ Industry since the age of $17-25$ years.

\section{Employment Period}

The entire section of the lathe worker X Industry has a work period of more than 5 years. A small percentage of workers have a working period 1-5 years. While most of the workers have worked above 5 years. This is because during the last 5 years $\mathrm{X}$ industry has not made new labor recruitment in the lathe section.

\section{Lung Disruption Condition}

Examination of lung disruption condition on lathe parts workers in the form of examination of pulmonary vital capacity or using FEV1 and FVC. Examination of FEV1 and FVC is informative assessment and often meaningless in assessing the progress of the pulmonary 
disease. Based on the results of examination of the lung using spirolab II obtained a fraction of workers misbehaving lung.

The

presence of impaired pulmonary at the lathe parts workers, then in a long time will cause pulmonary disease. A pulmonary disease that can appear due to disorders of the lung parenchyma disease is a restriction or interstitial diffuse pulmonary fibrosis ${ }^{4}$.

Association between Age and Lung Disruption Condition

Based on the test results cross-tabulations can be seen that a worker who has pulmonary disorders has age more 45 years. But still, many workers aged 45 years have conditions abnormal lung. It isn't similar to another research that capacity of the lungs will decrease along with the increase of age ${ }^{5}$. In addition, there is found a lathe part workers have impaired lung is in the age range 26-45 years.

Based on the results obtained by contingency coefficient value with 0,158 , age has a weak association with lung conditions lathe workers in $\mathrm{Z}$ Industry. This is similar to other research which mentioned the age is'not related to lung disruption condition ${ }^{67}$. In addition, another research that there is no meaningful relationship between pulmonary function disturbances with worker age in PT. Tonasa unit .

Association Employment Period with Lung Disruption Condition

Based on cross-tabulated results, lathe workers who have working period 5-10 years, nobody has impaired pulmonary. While all workers who experience disrupted lung have more than ten years working period. This contrasts to other statements which mention that there is a meaningful relationship between pulmonary function disturbances with employment working ${ }^{8}$ Pulmonary disease form of fibrosis appears because of the incubation period of dust over years ${ }^{9}$.

Results in coefficient of contingency coefficient with values 0.267 . Then it can be inferred relationships among powerful working period with the condition of the worker in the lung disruption lathe worker. A weak association between working period with the condition of lung disruption on lathe workers because most of the workers that have a working period over 10 years of age have the condition of a normal lung.

\section{Association Duration Working and Lung Disruption Condition}

Duration working has a significant association with lung impaired condition lathe worker in Z Industry. The result was similar to research conducted by Armaeni et al stated that the old work or long exposure is a powerful variable to cause interference lung10. As many as 10 people experienced workers with lung disorders with working hours 8 hours a day. Based on this it can be concluded that lathe worker has a risk of experiencing disruptions due to long exposure to work environment.

Lung disorder can occur because duration of a person's exposure to dusty environments continuously and the existence of other internal factors such as age, gender, working period, nutritional status, the habit of smoking, long exposure, protective tools themselves 9,11 . It means an association between duration working and lung impairment conditions on lathe workers could be due to other factors that also influence.

\section{Conclusion}

Age, employment period and duration working is associated with lung vital capacity of lathe workers. The thing that distinguishes is how strong association between two variables. On the variables of age and employment period with lung disruption condition have contingency coefficient value 0.158 and 0.279 meaning its have weak assosiation while duration working has contingency coefficient value 0.729 means its association is strong enough. Therefore, the higher of toxin substance, it will increased risk of damage to the lung function

\section{Recommendation}

Workers at lathe section are required to wear a protective mask in order to prevent or reduce the inhalation aluminum dust that will go into the lungs. Company parties also should always hold a medical check-up on a regular basis to check the health on lathe workers.

Conflict of Interest: All authors declare no potential conflicts of interest with respect to the research, 
authorship, and/or publication of this article.

Source of Funding: This is an article "Association between Duration Working with Lung Disruption Condition using Pulmonary Vital Capacity test on Lathe Worker at Yogyakarta"was supported by Faculty of Public Health, Airlangga University, Indonesia, 2017.

Ethical Clearance: Ethical Clearance took from Faculty of Public Health, Airlangga University, Indonesia Committee

\section{Reference}

1. Anes. N.I., Umboh. J. M.L., Kawatu. P.A.T. FaktorFaktor yang berhubungan dengan Gangguan Fungsi Paru-Paru pada Pekerja di PT. Tonasa Line Kota Bitung. Jurnal JIKMUVol 5 No. 3 Juli 2015

2. Ekawati., Suwondo,A. Perbedaan Kapasitas Vital Paksa Paru Tenaga Kerja pada Lokasi Pengecoran/ Percetakan dan Lokasi Pengikiran/Pembubutan di Industri Kerajinan Cor Alumunium "ED" Giwangan Yogyakarta. Jurnal Lingkungan Kesehatan Indonesia Vol 4 No.2 Oktober 2002

3. Tualeka, Abdul Rohim. Michael Agung Irianto, Adli Prasetyo, Ike Agustin Rachmawati dan Erwin Dyah Nawawinetu. Detoxification of Benzoic Acid in Workers Exposed to Toluene Using Food Rich in Glycine. Indian Journal of Public Health Research and Development. Vol 9, 2018, No.1 , JanuaryMarch 2018, page 64-69 (2018)

4. Peraturan Menteri Tenaga Kerja dan Transmigrasi (Permenakertrans). 2011. Nomor PER. 13/
MEN/X/2011 tentang Nilai Ambang Batas Faktor Fisika dan Faktor Kimia di Tempat Kerja. Jakarta.

5. Martin, T. D., Craver, J. M., Gott, J. P., Weintraub, W. S., Ramsay, J., Mora, C. T., \& Guyton, R. A. (1994). Prospective, randomized trial of retrograde warm blood cardioplegia: myocardial benefit and neurologic threat. The Annals of thoracic surgery, 57(2), 298-304.

6. Fishbach, F. Talaska., Dunning, M. Barnett. 2009. A Manual Of Laboratory and Diagnostic Test. China: Lippincot Williams \& Wilkins Publisher

7. Yuliawati, Ratna. 2015. Faktor-Faktor yang berhubungan dengan Gangguan Fungsi Paru pada Pekerja Pembuat Kasur (Studi Kasus di Desa Banjarkerta Karanganyar Purbalingga). Jurnal Ilmiah Manuntung. Vol 1(2) 154-158

8. Yulaeka, S. 2007. Paparan Debu Terhirup dan Gangguan Fungsi Paru pada Pekerja Industri Batu Kapus. Tesis. Semarang, Universitas Diponogoro.

9. Suma'mur P. K. 2009. Higiene Perusahaan dan Kesehatan Kerja (Hiperkes) Jakarta: Sagung Seto

10. Armaeni, Dewi Erka dan Widajati, Noeroel. Hubungan Paparan Debu Kapur dengan Status Faal Paru pada Pekerja Gamping. Indonesian Journal of Occupational Safety and Health Vol. 6 No.1 Jan-Jun 2016: 61-70

11. Munawar, Samik. 2014. Analisis Pengaruh Paparan Debu Kayu terhadap Faal Paru. Tesis. Surabaya: Universitas Airlangga. 